\title{
IMPLEMENTASI KURIKULUM MULTIKULTURAL DI SEKOLAH DASAR
}

\section{IMPLEMENTATION OF MULTICULTURAL CURRICULUM IN PRIMARY SCHOOL}

\author{
Sutjipto \\ Pusat Kurikulum dan Perbukuan, Balitbang, Kemendikbud \\ Jl. Gunung Sahari Raya, Nomor 4A, Jakarta Pusat \\ e-mail: sutjipto.55@gmail.com
}

Naskah diterima tanggal: 8-06-2017, disetujui tanggal: 31-06-2017

\begin{abstract}
This study is to examine the empirical facts of multicultural curriculum implementation in primary schools in South Tangerang City. The method used was descriptive qualitative and the main data were collected from focus group discussions and school observation. Data analysis techniques using descriptive statistics. The study was conducted from July 2016 to November 2016. The population of this study were teachers and elementary school students in the city. The sample was taken by purposive sampling. The result show that the existing curriculum documents have significantly integrated multicultural values and the teachers and principals' understanding of multicultural knowledge lies in a significant category. Concerning the implementation of the curriculum, it is revealed that it is not significantly controlled in schools, it has not significantly encouraged the reinforcement of multicultural values, and it has not voiced significant harmony for educational culture, school curriculum, and multiculturalism through empowerment. In conclusion, the implementation of multicultural curriculum in primary schools in this city has not changed for the better direction.
\end{abstract}

Keywords: curriculum implementation, multicultural curriculum, primary school

\begin{abstract}
Abstrak: Tujuan penelitian ini adalah mengkaji fakta empiris implementasi kurikulum multikultural di sekolah dasar. Metode penelitian yang digunakan adalah deskriptif kualitatif. Data utama dikumpulkan dengan diskusi kelompok terpumpun dan observasi sekolah. Teknik analisis data menggunakan statistik deskriptif, yaitu penggambaran data dengan pola deskripsi atau telaah. Penelitian dilakukan pada bulan Juli 2016 sampai dengan November 2016. Populasi dari penelitian ini adalah guru dan siswa sekolah dasar di Kota Tangerang Selatan. Sampel penelitian diambil secara purposive sampling. Hasil penelitian menunjukkan bahwa dokumen kurikulum yang ada secara signifikan telah mengintegrasikan nilai-nilai multikulturalisme dan pemahaman guru serta kepala sekolah terhadap pengetahuan multikultural berada pada kategori cukup signifikan. Berkaitan dengan implementasi kurikulum, terdapat tiga temuan, yakni: belum dikendalikan secara signifikan dengan baik di sekolah; belum mendorong secara signifikan penguatan nilai-nilai multikultural; dan belum menyuarakan keharmonisan secara signifikan antara budaya pendidikan, kurtur sekolah, dan multikulturalisme melalui pemberdayaan. Dengan demikian, pengimplementasian kurikulum multikultural di sekolah dasar di Kota Tangerang Selatan umumnya belum berubah ke arah yang lebih baik.
\end{abstract}

Kata kunci: implementasi kurikulum, kurikulum multikultural, sekolah dasar 


\section{PENDAHULUAN}

Terkait kurikulum pendidikan multikultural (keberagaman budaya) terdapat beberapa catatan. Pertama, semua negara di dunia memiliki kebijakan kurikulum pendidikan yang berpihak pada prinsip-prinsip pembelajaran berbasis keberagaman. Kedua, keanekaragaman sosial-budaya dalam ikatan kemasyarakatan yang membentuk kelompok telah menyebar ke semua peradaban di dunia yang mensyaratkan perilaku yang saling toleransi satu sama lain untuk dicerminkan dalam kurikulum. Ketiga, adanya kelompok yang berbeda ras, suku, agama, adat-istiadat, dan golongan yang saling berinteraksi dalam hidup bersama, meski terdapat perbedaan dipastikan mendambakan kedamaian, kerukunan, dan harmoni sosial. Kedamaian yang ditandai sebagai keutuhan, keselarasan, dan keharmonisan dalam hubungan antarmanusia dan lingkungan diperlukan perawatan dan penumbuhan melalui penerapan dalam suatu kurikulum pendidikan.

Kurikulum pendidikan yang sarat dengan nilai-nilai keberagaman dan perdamaian memerlukan proses perjuangan pembelajaran di sekolah. Hasil penelitian Mitchell (2010) mengungkapkan bahwa fungsi berbagai proses yang terkait dengan demokrasi, pemerintahan, pembangunan dan sekuritisasi merupakan dasar untuk perdamaian pada aktivitas manusia sehari-hari sebagai wahana untuk memahami hubungan yang kompleks antara aktor internasional dan lokal dalam konteks perdamaian. Temuan ini memberi makna bahwa interaksi antara jenis kesatuan-kesatuan sosial yang majemuk dalam segala proses berbangsa dan bernegara melalui sebuah kurikulum multikultural yang harmonis akan berdampak pada dinamika sosial kemasyarakatan. Untuk itu, diperlukan komitmen semua pihak.

Kurikulum pendidikan multikultural juga merupakan wahana untuk meningkatkan kapasitas individual dan sosial setiap siswa dalam hal kompetensi sosial berupa kemampuan sosialisasi, beradaptasi, berinteraksi dalam masyarakat, menjalin relasi sosial, memupuk sikap toleransi dalam kehidupan dinamika masyarakat, dan menanamkan penghargaan atas realitas kemajemukan sosial. Secara individual, penerapan kurikulum multikultural akan meningkatkan pengetahuan, informasi, penyadaran, dan kemampuan teknis kemasyarakatan, sehingga siswa memiliki kemampuan untuk memperkuat daya sintas (survival) dalam kawasan realitas kemajemukan kehidupan sosial. Sebuah studi longitudinal oleh Thompson, dkk. (2009) menunjukkan bahwa pengalaman berbasis lapangan memiliki dampak pengetahuan multikultural terhadap siswa dan mereka juga merasakan adanya potensi diri (self-efficacy).

Indonesia sebagai bangsa yang majemuk, penguatan dimensi kurikulum multikultural harus dilakukan untuk dapat mengembangkan orientasi dan wawasan mengenai realitas kehidupan sosial kebangsaan yang pluralistik di sekolah. Kurikulum pendidikan multikultural membangun kesadaran setiap siswa tentang kenyataan kemajemukan dalam kehidupan bermasyarakat, berbangsa, dan bernegara. Siswa diharapkan peka dan menyadari bahwa bangsa ini dibangun di atas landasan keberagaman agama, etnik, ras, budaya, dan adat-istiadat, yang menuntut kesediaan semua pihak untuk saling menerima keberadaan yang lain. Struktur negara-bangsa ini bercorak multikultural, sehingga setiap elemen bangsa harus bersedia hidup secara konsisten. Karenanya, implemetasi kurikulum dalam kerangka pengembangan budaya sekolah hendaknya mencerminkan kehidupan yang sesungguhya, yaitu bersatu dalam keberagaman dan beragam dalam kesatuan.

Kurikulum pendidikan multikultural menjadi sangat penting terutama untuk menumbuhkan nilai-nilai kebinekaan, toleransi, dan memperkuat basis solidaritas sosial. Penguatan nilai-nilai multikultural pada pembelajaran itu mutlak diperlukan untuk dapat mereduksi atau mengeliminasi potensi konflik dalam masyarakat majemuk. Sebagai suatu bentuk strategi membangun keadaban, kurikulum multikultural juga dimaksudkan untuk pembinaan sikap mental 
dan karakter, pemupukan inovasi dan kreativitas, kepemimpinan, dan jiwa kewirausahaan siswa.

Studi longitudinal Maddux, dkk. (2014) mengungkapkan bahwa pendekatan psikologis individu ketika berada pada lingkungan multikultural, di mana mereka terlibat dengan budaya yang berbeda dan menentukan pertumbuhan kompleksitas integratif, ternyata mampu meningkatkan kesuksesan karir peluang kerja mereka berikutnya secara lebih profesional. Hasil penelitian Maddux, dkk. (2014) tersebut memberi makna bahwa tenaga kerja yang profesional dapat ditingkatkan melalui pendidikan dan dipengaruhi dengan penerapan nilai-nilai multikultural. Dalam arti, melalui kurikulum pendidikan multikultural terjadi upaya membangun daya saing bangsa dan harmoni sosial. Dengan demikian, siswa dilatih menjadi lebih terbuka menerima segala perbedaan, memiliki sikap toleransi untuk menghadirkan kehidupan sosial, dan pranata lain yang melingkupinya, sehingga kompetisi global dan kohesi sosial di dalam masyarakat plural akan tercipta. Secara sosiologi, merujuk pada penelitian Keddie (2014) bahwa dampak kohesi sosial, persatuan dan solidaritas sosial bisa dihasilkan melalui konsep multikulturalisme. Sementara pada sisi lain, faktor-faktor yang berdampak membangun, menurut hasil penelitian Schoorman \& Bogotch (2010) menunjukkan bahwa hal-hal yang positif berfungsi sebagai titik awal untuk dialog tentang re-konseptualisasi peran multikultural.

Implementasi kurikulum pendidikan multikultural yang sarat dengan pengalaman sosial dan situasi kehidupan multikultural beserta kedekatan pada modernisasi budaya yang didesain masyarakat sekolah, berada pada posisi utama untuk menentukan cara hidup kelompokkelompok lainnya, dalam hal afiliasi pada tradisi agama dan sosial-budaya. Pengalamanpengalaman yang membentuk multikultural ini adalah krisis, gejolak dan penyisihan etnik, seperti yang telah terjadi dalam konflik-konflik sosial selama ini. Nilai-nilai sosial yang menyangkut cara hidup bersama yang dianut oleh semua pihak disadari akan membuka tempat bagi koeksistensi identitas masyarakat yang berbeda-beda sebagai cara untuk percaya dan hidup bersama untuk saling mengerti hendaknya merupakan misi yang diemban oleh kurikulum.

Beberapa hasil penelitian mengenai pendidikan multikultural telah dilaksanakan dengan berfokus pada keragaman agama, kemasyarakatan, dan perbedaan etnis (Olmedo, 2004; Mentz \& van der Walt, 2007; Lykogianni, 2008; Okoye-Johnson, 2011; Miafodzyeva, dkk., 2013; Agirdag, dkk, 2016; Solano-Campos, A. 2015). Namun, studi-studi tersebut umumnya tidak memberi tumpuan khusus pada aspek implementasi kurikulum dan hubungannya dengan keberhasilan internalisasi nilai-nilai multikultural. Studi-studi tersebut lebih menumpukan pada peranan pendidikan multikultural dalam mengurangi sikap rasial, kesiapan guru di mana mereka mengajar di sekolah-sekolah multikultural, keragaman agama, dan isu-isu kemasyarakatan seperti transnasionalisme, imigrasi ilegal maupun rasisme.

Sementara itu, penelitian di Indonesia umumnya lebih berkaitan dengan aspek-aspek praktik pendidikan, lintas budaya, muatan dalam buku, nilai-nilai pada mata pelajaran, dan masyarakat keagamaan (Wihardit, 2010; Nurhayati, 2011; Zuriah, 2011; Heryadi \& Silvana, 2013; Purwanto, dkk, 2013). Benang merah dari dua koridor penelitian tersebut, yang belum menggambarkan impresi moderasi hubungan kurikulum dan yang fokus pada implementasinya menjadi tumpuan kajian yang menarik untuk dilaksanakan.

Secara sosiologi, merujuk pada pandangan Banks (2007), multikultural adalah cara memandang realitas dan cara berpikir, dan bukan hanya konten tentang beragam kelompok etnis, ras, dan budaya. Dalam konteks kemasyarakatan, multikultural dapat dimaknai bahwa dalam sebuah masyarakat, bangsa, atau negara yang terbentuk karena adanya keanekaragaman sosial-budaya. Keanekaragaman tersebut merupakan sesuatu yang tidak terbantahkan. Negara-bangsa Indonesia dikenal dengan 
masyarakatnya yang multikultural atau majemuk karena terdiri atas keanekaragaman agama, suku, etnis, budaya, adat-istiadat, dan golongan.

Tilaar (2004) memberi gambaran, paling tidak terdapat tiga program multikulturalisme yang dapat dikuatkan melalui kurikulum, yaitu bahwa pendidikan multikultural hendaknya: 1 ) didasarkan pada kesetaraan manusia, 2) ditujukan pada terwujudnya manusia Indonesia yang cerdas, dan 3) harus berprinsip pada globalisasi. Ketiga program tersebut dapat dijadikan rujukan pembuat keputusan dalam menguatkan dan menginternalisasikan nilai-nilai multikultural ke dalam kurikulum pendidikan.

Di banyak negara, implementasi konsep multikulturalisme dalam kurikulum pendidikan menjadi perhatian yang sangat serius. Di Irlandia, misalnya, hasil penelitian Faas \& Ross (2012) memberi rekomendasi bahwa peran sekolah dalam mengembangkan kewarganegaraan dan konsep identitas terhadap masyarakat migran di Irlandia berargumen bahwa kurikulum pada tingkat pendidikan dasar menekankan keragaman dan kewarganegaraan aktif dalam masyarakat majemuk memiliki porsi lebih besar daripada kurikulum pada tingkat pendidikan menengah. Pada contoh lain, dalam kajiannya terhadap bangsa Amerika Serikat yang dianggap tanah imigran dan memiliki keragaman budaya, Ford (2013) mengungkapkan bahwa sekolah dan guru harus responsif budaya, dengan cara penguatan persepsi dan apresiasi siswa dalam menghormati yang lain melalui implementasi pendidikan multikultural.

Implementasi kurikulum multikultural pada jenjang pendidikan dasar dan menengah hendaknya sejalan dengan keseluruhan konsep pendidikan multikultural. Konsep pendidikan multikultural pada hakikatnya mengutamakan persamaan (equality) atau mengedepankan keberagaman (diversity). Dari dua pilihan tersebut, konsep mana yang akan ditempuh oleh pelaksana kebijakan, pengimplementasiannya tentu akan disesuaikan dengan konteks sosialbudaya masing-masing daerah, masyarakat, atau sekolah. Penanaman nilai-nilai multikultural seyogianya mencakup suatu pemahaman konsep, perbuatan penghargaan serta penilaian atas budaya seseorang, serta suatu penghormatan dan keingintahuan tentang budaya etnis orang lain dalam komunitas masyarakat. Bahkan, isu pembelajaran multikultural mendapatkan perhatian yang cukup serius dalam pembahasan di al-Qur'an dan al-Sunnah (Trauna, 2010).

Berdasarkan uraian di atas, terdapat dua pertanyaan mendasar yang perlu digali melalui penelitian. Pertanyaan pertama, teori siapakah yang sesuai untuk memotret implementasi kurikulum multikultural di sekolah. Rumusan seorang ahli multikulturalisme bernama James Albert Banks tentang wawasan pendidikan multikultural yaitu perkembangan historis, dimensi, dan praktiknya patut dijadikan rujukan. Menurutnya, mutlikultural adalah konsep, ide atau falsafah sebagai suatu rangkaian kepercayaan (set of believe) dan penjelasan yang mengakui dan menilai pentingnya keragaman budaya dan etnis di dalam membentuk gaya hidup, pengalaman sosial, identitas pribadi, kesempatan-kesempatan pendidikan dari individu, kelompok maupun Negara (Banks, 2007).

Pertanyaan kedua, budaya multikultural seperti apa yang layak diperjuangkan melalui kurikulum di sekolah. Pertanyaan kedua ini selaras dengan kajian Lie (2014) yang menyintesiskan pelajaran multikultural seperti apa yang harus negara berikan kepada imigran secara signifikan, seperti Korea Selatan, yang diambil dari pengalaman negara-negara lain. Masih menurut Lie (2014), kebijakan multikulturalisme seperti apa yang mereka adopsi dan mengapa itu perlu. Kedua pertanyaan tersebut, memberikan makna isu sentral, bahwa multikulturalisme tidak mengurangi keragaman, melainkan juga untuk menentukan prinsip-prinsip dan prosedur di mana perbedaan dinegosiasi ulang atas nama keadilan (Arneil \& MacDonald, 2010).

Apa pun isu terkait dengan implementasi kurikulum multikultural di sekolah, apabila 
dilakukan secara saksama akan membuahkan opsi kebijakan yang sarat makna. Penelitian Banting et al. (2006) terhadap multikulturalisme dan kesejahteraan negara mengungkap fakta bahwa penelitian lintas-nasional baru-baru ini menunjukkan bahwa tidak ada bukti dari kecenderungan yang sistematis untuk kebijakan multikulturalisme yang sanggup melemahkan kesejahteraan negara. Begitu pula Bachvarova (2014) dalam kajiannya juga berpendapat bahwa manfaat dari multikulturalisme berbasis nondominasi lebih berbobot dibandingkan dengan pendekatan egaliter liberal. Pendekatan ini difokuskan pada "kualitas moral hubungan antara aktor sentral" dan menguatnya keberlangsungan perlakuan antara kelompok-kelompok dalam komunitas. Dengan merujuk dua hasil tersebut, dapat dimaknai bahwa pengimplementasian kurikulum pendidikan multikultural memiliki kontribusi positif terhadap menguatnya tatanan kesejahteraan masyarakat.

Berdasarkan berbagai penelaahan di atas, penelitian tentang pengimplementasian kurikulum pendidikan multikultural di Sekolah Dasar, Banks \& Banks (2004) menjelaskan bahwa terdapat lima dimensi yang harus ada. Pertama, adanya integrasi isi dalam kurikulum (content integration) yang melibatkan keragaman dalam satu kultur pendidikan yang tujuan utamanya adalah menghapus prasangka. Kedua, konstruksi ilmu pengetahuan (knowledge construction) yang diwujudkan dengan mengetahui dan memahami secara komprehensif keragaman yang ada. Ketiga, pengurangan prasangka (prejudice reduction) yang lahir dari interaksi antarkeragaman dalam kultur pendidikan. Keempat, pedagogik equitas/kesetaraan (equity pedagogy) yang memberi ruang dan kesempatan yang sama kepada setiap elemen yang beragam. Kelima, pemberdayaan budaya sekolah (empowering school culture). Hal yang kelima ini adalah tujuan dari pendidikan multikultural, yaitu agar sekolah menjadi elemen pengentas sosial (transformasi sosial) dari struktur masyarakat yang timpang menjadi struktur yang berkeadilan.
Kelima dimensi yang dirujuk, selanjutnya memandu koridor permasalahan penelitian yang akan diungkapkan, yaitu bagaimana realita dari integrasi isi dalam kurikulum, bentuk konstruksi ilmu pengetahuan, model pengurangan prasangka, kesetaraan pengajaran, dan pemberdayaan budaya yang terimplementasi melalui kurikulum di sekolah? Dengan demikian, tujuan utama dari penelitian ini adalah untuk mengkaji fakta empiris terkait dengan pengimplementasian kurikulum multikultural di sekolah dasar ditinjau dari kelima dimensi tersebut.

\section{METODE}

Penelitian ini akan mengangkat potret sosialbudaya pada konteks belajar (Dominguez \& Hollstein, 2014; Ford, 2014). Sementara itu, jenis penelitian yang digunakan adalah deskriptif kualitatif.

Populasi dari penelitian ini adalah guru, tenaga kependidikan, dan siswa sekolah dasar di Kota Tangerang Selatan. Sampel penelitian didasarkan atas purposive sampling dengan penetapan sampel secara nonprobability sampel.

Ada empat sekolah yang dijadikan sampel, yakni: 1) SD Negeri Benda Baru 03, Jl. Borobudur Raya No. 11, Benda Baru, Pamulang, Tangerang Selatan; 2) SD Negeri Benda Baru 02, Jl. Borobudur Raya No. 11, Benda Baru, Pamulang, Tangerang Selatan; 3) SD Negeri Serua 03, Bukit Indah, Ciputat, Tangerang Selatan; dan 4) SD Negeri Serua 05, Bukit Indah, Ciputat, Tangerang Selatan.

Masing-masing sekolah diambil satu kelas IV, satu kelas V, dan satu kelas VI sebagai sampel, sedangkan guru yang mengajar di kelas tersebut sekaligus dijadikan responden. Dengan demikian, jumlah responden sebanyak 12 orang.

Data dikumpulkan dengan menggunakan dua cara, yakni: 1) diskusi kelompok terpumpun dan 2) observasi sekolah. Model observasi menurut kajian Grice, dkk. (2016) merupakan sebuah alternatif untuk konseptualisasi data yang bergeser dari statistik agregat dan tanpa pengujian hipotesis signifikansi. 
Penelitian dilakukan pada bulan Juli sampai dengan November 2016. Teknik analisis data menggunakan statistika deskriptif, yaitu penggambaran data dengan pola deskripsi atau telaah atau simpulan agar mudah dibaca dan bermakna.

\section{HASIL DAN PEMBAHASAN}

Dari lima dimensi yang dijadikan konstruk penelitian sebagaimana disebutkan pada pendahuluan, hal itu sekaligus juga menandakan ada lima kategori/ukuran/koridor yang akan disorot terkait dengan penerapan kurikulum multikultural di SD. Oleh karena itu, deskripsi hasil dan pembahasan penelitian difokuskan pada kelima koridor tersebut.

Sebagai gambaran, Tabel 1 dan Tabel 2 adalah profil sekolah sampel. Berkaitan dengan asal daerah, baik siswa maupun guru umumnya berasal dari suku: Jawa, Sunda, Betawi, Minangkabau, Lampung, Dayak, Batak, Manado, Palembang, Bengkulu, dan Bali dengan mayoritas siswa dan guru merupakan Suku Sunda dan Jawa.

\section{Integrasi Pendidikan dalam Kurikulum (Content Integration)}

Dokumen kurikulum yang dipakai di sekolah saat ini antara lain standar kompetensi lulusan, kerangka dasar dan struktur kurikulum, kompetensi dasar, silabus, rencana pelaksanaan pembelajaran, dan dokumen pendukung lainnya, seperti buku pedoman dan buku pelajaran yang diterapkan di sekolah. Dari data yang dihimpun melalui diskusi kelompok responden terpumpun terungkap bahwa dokumen kurikulum tersebut tidak mengandung unsur kata atau ungkapan maupun ilustrasi yang mendiskreditkan keberagaman. Menurut semua responden, hari-hari di sekolah tidak ditemukan adanya permasalahan terkait dengan gesekan-gesekan kultural antarindividu, seperti ungkapan kebencian, perilaku kekasaran, dan ujaran intimidasi. Begitu pula, baik secara tertulis maupun tak tertulis yang secara stereotip, misalnya mengajak kepada pembaca atau orang lain untuk mendiskreditkan yang lain, membentuk kelompokkelompok berdasarkan golongan, suku, etnis masing-masing terhadap kelompok etnis yang lain.

Tabel 1 Kondisi Siswa

\begin{tabular}{|c|c|c|c|c|c|c|c|}
\hline \multirow[t]{2}{*}{ No } & \multirow[t]{2}{*}{ Sekolah } & \multirow{2}{*}{$\begin{array}{c}\text { Jumlah } \\
\text { Siswa }\end{array}$} & \multicolumn{5}{|c|}{ Pemeluk Agama } \\
\hline & & & Islam & Kristen & Katolik & Budha & Hindu \\
\hline 1 & SD Negeri Benda Baru 03 & 537 & 507 & 15 & 8 & 3 & 4 \\
\hline 2 & SD Negeri Benda Baru 02 & 284 & 270 & 9 & 3 & 1 & 1 \\
\hline 3 & $\begin{array}{l}\text { SD Negeri Serua 03, Bukit } \\
\text { Indah }\end{array}$ & 1.051 & 1.002 & 24 & 10 & 6 & 9 \\
\hline 4 & $\begin{array}{l}\text { SD Negeri Serua 05, Bukit } \\
\text { Indah }\end{array}$ & 591 & 577 & 12 & 2 & - & - \\
\hline
\end{tabular}

Tabel 2 Kondisi Guru

\begin{tabular}{llcccccc}
\hline No & \multicolumn{1}{c}{ Sekolah } & Jumlah & \multicolumn{5}{c}{ Pemeluk Agama } \\
\cline { 3 - 7 } & & Guru & Islam & Kristen & Katolik & Budha & Hindu \\
\hline 1 & SD Negeri Benda Baru 03 & 21 & 21 & - & - & - & - \\
2 & SD Negeri Benda Baru 02 & 16 & 16 & - & - & - & - \\
3 & SD Negeri Serua 03, Bukit & 36 & 36 & - & - & - & - \\
& Indah & & & & & - & 1 \\
& SD Negeri Serua 05, Bukit & 20 & 19 & - & - & - & \\
\hline
\end{tabular}


Yang dimaksud stereotip dalam hal ini adalah tentang budaya suku tertentu daerah asal siswa (Tabel 1), yaitu sebagai karakter maupun atribut-atribut yang dianggap melekat sebagai identitas suku, etnis, dan kelompok. Stereotip dapat bersifat positif maupun negatif, baik berkaitan dengan kelompok sendiri maupun kelompok di luar dirinya. Dalam banyak kasus, stereotip sering bersifat berlebihan, cenderung negatif daripada positif, dan sulit diubah meskipun telah secara nyata berinteraksi dengan seseorang yang memiliki karakteristik bertentangan dengan label stereotip yang ada. Pola semacam ini, di kemudian hari dapat menimbulkan prasangka bagi orang lain atau kelompok lain.

Secara sosiologis, menurut hasil penelitian Gordijn, dkk. (2008) mengungkapkan bahwa prasangka diprediksi lebih negatif daripada perasaan positif. Timbulnya prasangka bagi seseorang atau kelompok merupakan faktor yang potensial menciptakan konflik antarkelompok atau antaridentitas (agama, etnis, dan suku). Prasangka dapat menimbulkan adanya kesulitan interaksi dan kohesi sosial bagi seluruh komunitas sosial bersangkutan yang pada gilirannya dapat memicu konflik sosial. Konflik sosial akan bertambah berlebihan manakala dalam beberapa kondisi, seseorang atau kelompok hanya bertindak atas dasar prasangka. Pengalaman menunjukkan, baik di manapun, konflik antaridentitas (agama, etnis, dan suku) sering berkembang menjadi tragedi yang memilukan.

Dari fakta yang terungkap di atas, dapat dimaknai bahwa sekolah umumnya telah berupaya mengajarkan cara bertoleransi dan menghormati perbedaan melalui media pembelajaran berbagai mata pelajaran dalam wujud pengintegrasian pemahaman. Dengan melalui pencerahan pembelajaran pada konteks keragaman, diharapkan berdampak pada makna sosial. Integrasi nilai-nilai kemajemukan yang dijalani oleh siswa saat belajar maupun berinteraksi dengan yang lain diyakini akan mampu menghapus prasangka negatif. Pada konteks lain, misalnya teks-teks pembelajaran yang digunakan, juga telah mengintegrasikan aura kemajemukan yang akan dapat mengurangi timbulnya prasangka. Apabila semua itu dapat dibiasakan dan dibudayakan, menurut responden, sekolah dapat menjadi tempat untuk menyemai dan menghargai perbedaan yang nantinya berguna bagi siswa dalam kehidupan bermasyarakat, berbangsa, dan bernegara. Namun, kenyataannya hal tersebut belum sepenuhnya dapat diwujudkan.

Sementara itu, dari observasi sekolah, terungkap bahwa budaya sekolah dalam kerangka mempromosikan nilai-nilai inklusif guna merawat dan mengelola multikulturalisme belum diprogramkan secara baik. Misalnya, walau dalam kelas terdapat siswa yang berbeda agama, ritual doa yang dilaksanakan saban hari umumnya masih dilakukan untuk satu agama tertentu. Begitu pula kegiatan lainnya, seperti pentas budaya (kesenian, berpakaian, dan penggunaan atribut lainnya) yang mengusung tema asal daerah juga belum tergarap secara proporsional. Pentas budaya yang dirancang setiap tahun dengan baik, selain akan mampu membangkitkan energi perjumpaan sosialekonomi-kultural secara khidmat dalam kemajemukan, sekaligus juga sebagai ajang kreativitas siswa. Berdasarkan hasil penelitian, ditemukan bahwa secara keseluruhan, pembelajaran multikultural dapat menjadi mekanisme penting di mana pengalaman hidup asing mampu menyebabkan peningkatan kreativitas (Leung \& Chiu, 2010; Maddux, dkk. 2010).

Secara empiris, fakta kultural yang telah terbangun di sekolah selama ini umumnya belum banyak berubah, dalam arti tidak ditemukan dampak terhadap munculnya prasangka negatif bagi orang satu ke orang lain, kelompok satu dengan kelompok lainnya, etnis satu dengan lainnya, maupun penganut agama tertentu dengan penganut agama yang berbeda. Hal ini ditandai antara lain tidak ditemukan ujaranujaran negatif oleh siswa kepada teman yang beda suku. Misalnya, dasar wong Jowo lelet, dasar Menado (menang aksi doang), dasar BTL 
(Batak tembak langsung), dan lainnya. Data tersebut diperkuat oleh catatan para kepala sekolah, bahwa selama tiga tahun terakhir umumnya tidak muncul beragam hal yang dapat menumpahkan emosi, seperti ujaran-ujaran kebencian, penistaan, hina-menghina, dan olokolok lainnya disertai hal-hal yang merusak kemajemukan, keberagaman, dan kebhinekaan.

Sikap saling memerlukan dan bergantung menurut catatan kepala sekolah cukup baik . Pandangan itu kemudian membentuk aktivitas bersama dan hasrat untuk satu. Aktivitas sekolah yang terbentuk dapat dikatakan satu untuk semua dan semua untuk satu. Indikator tersebut diperkuat oleh adanya beberapa poster ajakan/himbauan/kemauan yang terdapat di lingkungan sekolah, seperti $7 \mathrm{~K}$ (kebersihan, keindahan, kenyamanan, ketertiban, kesehatan, keamanan, dan kerindangan), menyontek awal dari korupsi, tinggalkan perilaku burukmu, mari memberi bantuan bagi yang kemalangan, aku malu datang ke sekolah terlambat, budayakan 6-S (salim-senyum-sapa-salam-sopan-santun), no cheating-no bullying-no smoking, sholatlah sebelum kamu disholatkan, dan lainnya.

Menurut catatan para kepala sekolah, pada tahap awal dirasakan bahwa membangun nilainilai multikulturalisme di sekolah tidaklah mudah. Ditemukan adanya sebagian kecil warga sekolah yang kurang peduli atau bersikap menolak. Tradisi, norma-norma sosial, harapan-harapan tidak mudah menjadi kebiasaan warga sekolah yang pro-sosial. Secara sosiologis, merujuk pada hasil penelitian Peterson \& Søndergaard (2011) diungkapkan bahwa untuk mengatasi kontroversi tentang budaya diperlukan promosi percakapan atau dialog. Setelah melalui berbagai strategi, seperti rapat dinas, adanya komitmen bersama, dibuat tertulis, dan lainnya, lambat laun tampak membuahkan hasil. Keyakinan kepala sekolah memperkuat bahwa apa pun tantangannya, perilaku baik yang mengedepankan kemajemukan sangat dibutuhkan untuk memajukan sekolah dan peradaban secara lebih luas. Salah satu pertimbangannya karena di dalamnya terdapat orang-orang beragam latar belakang identitas keluarga yang anak-anaknya bersekolah.

Dari temuan yang diungkap di atas dapat dimaknai bahwa berbagai upaya untuk membangun pengintegrasian pendidikan dalam kurikulum multikultural demi kebaikan di sekolah telah diupayakan dilaksanakan, bahkan tidak mengenal kata menyerah. Namun, di sekolah hasilnya memang masih belum memperlihatkan jejaknya. Berbagai hambatan yang muncul, menurut para kepala sekolah karena adanya keengganan sebagian kecil warganya terhadap aksi-aksi aktualisasi nilai-nilai menghargai perbedaan. Menurut kepala sekolah, keteladanan yang kuat dalam bingkai keberagaman, seruan menghargai yang lain yang tidak menghormati akan keberagaman pun belum bisa disulap menjadi sekolah yang ramah dengan kemajemukan.

Padahal, salah satu indikator keberhasilan pengimplementasian kurikulum multikultural di sekolah adalah adanya keteladanan peran manajemen terhadap nilai-nilai keadaban publik dalam suatu sekolah yang relatif majemuk. Praksis seperti itu, senyampang dengan hasil penelitian Engelkamp \& Glaab (2015) yang mengungkapkan bahwa, dengan cara menyerukan budaya toleransi dan etika hospitality yang merayakan ambiguitas normatif sebagai sumber untuk dialog dapat menguatkan dalam membangun budaya. Budaya sekolah sampel yang dimaksud, antara lain keagamaan/ibadah, kerjasama, sadar akan tugas dan tanggung jawab, memberikan layanan terbaik, kerja dengan kegembiraan, saling menghormati, disiplin, sopan-santun, jujur, bersih, dan empati.

Dengan model seperti itu, tampak bahwa budaya sekolah belum dibangun secara adekuat. Budaya sekolah dijadikan ruh bagi terciptanya iklim sekolah yang kondusif untuk mengurangi prasangka negatif dan saling curiga. Proses pembelajaran yang mengintegrasikan internalisasi nilai-nilai kebersamaan dalam implementasi kurikulum sekolah yang mampu menepis berbagai keragaman telah dilakukan, tetapi tampak belum menjadi budaya. Manajemen 
sekolah hanya meyakini bahwa perilaku komunitas sekolah yang pro-sosial akan menumbuhkembangkan ikatan antarwarga sekolah. Persepsi seperti itu, senyampang dengan hasil penelitian Rutland, dkk. (2010) yang mengungkapkan bahwa prasangka harus dieliminasi sedemikian rupa dalam konteks pembangunan sosial-kognitif dan interaksi antara moralitas dan identitas kelompok. Dengan demikian, kontak antarkelompok mampu membangun bagaimana siswa menganggap identitas kelompok (dan norma-norma kelompok) bersama dengan mereka mampu mengembangkan keyakinan moral tentang keadilan dan berkeadilan. Moralitas dan identitas kelompok memiliki pengaruh yang sangat signifikan terhadap berbagai kebijakan sekolah. Penelitian Betts \& Hinsz (2013) mengungkapkan bahwa kelompok lebih bermusuhan dari individu ketika ditolak.

\section{Konstruksi Ilmu Pengetahuan (Knowledge Construction)}

Data yang dihimpun melalui diskusi kelompok terpumpun terungkap bahwa semua responden memberikan tanggapan bahwa pada saat pembelajaran di sekolah baik di kelas maupun di luar kelas, senantiasa melakukan hal-hal yaitu 1) mengajar tentang pengetahuan berkaitan dengan mata pelajaran, 2) membimbing siswa ke arah kebaikan, 3) menasihati siswa yang memiliki perilaku yang tidak sesuai norma, 4) menularkan budaya, dan 5) menanamkan kebaikan kepada orang lain melalui contoh konkret. Konstruk yang terbentuk tersebut menandakan bahwa pemahaman guru dan kepala sekolah terhadap multikulturalisme cukup signifikan. Sekolah dianggap memiliki makna sosial karena internalisasi amalan-amalan yang dibiasakan amat berguna dalam proses pembudayaan.

Pada sisi yang lain, praksis sebagaimana terungkap di atas, menandakan bahwa peran kepala sekolah tentang konstruksi pembelajaran multikulturalisme juga cukup signifikan. Namun, hal tersebut paradoks dengan para gurunya.
Pengelola pembelajaran di kelas umumnya memahami akan konsep multikulturalisme, tetapi masih belum kuat dalam tataran penerapan keberagaman. Oleh karena itu, guru seyogianya diajak memahami tidak hanya mengajarkan akademik, melainkan juga toleransi, sopan santun, dan berempati. Di samping itu, dalam setiap aktivitas pendidikan di sekolah senantiasa tetap mempertahankan pengajaran mata pelajaran sebagai akar tradisi pembelajaran yang diperkuat dengan pengetahuan kemajemukan Indonesia, sehingga siswa mengerti bagaimana menghargai dan bertanggung jawab. Untuk itu, kepala sekolah hendaknya selalu didorong membuka pilihan makna, bagaimana kepala sekolah sebanyak mungkin mengatasi tantangan dalam implementasi pendidikan multikultural (Santamaría, 2013; du Plessis \& Marais, 2015).

Di balik tersajinya bahan pembelajaran yang dimaknai sebagai ilmu pengetahuan, terkandung banyak nilai bahkan budaya dan kerukunan yang harus dihayati siswa. Dalam membentuk perilaku masyarakat sekolah seperti itu, mengetahui dan memahami instrumen kurikulum pendidikan multikultural memegang peran yang amat penting. Hal tersebut untuk memenuhi, membentuk peradaban bangsa, dan juga menjadi inspirasi peradaban dunia. Menurut semua responden, mendekatkan siswa pada pengetahuan mengenai toleransi akan keberagaman budaya, suku, agama, dan golongan akan menguatkan toleransi dalam kehidupan kebhinekaan di sekolah yang merupakan simbol masyarakat yang beradab. Indonesia yangdidirikan dengan ciri kodrati majemuk, beragam, dan bhineka, baik dalam agama, suku, maupun ras adalah cerminan di sekolah sampel yang merupakan kenyataan yang tak terelakkan.

Namun, pada temuan yang lain, gempitanya tanggapan responden terhadap premis pemahaman konsep multikultural ternyata tidak berbanding lurus dengan dinamika aktivitas kesehariannya di sekolah. Potret yang menggambarkan bahwa warga sekolah mampu menggairahkan kesadaran dan tekad yang kuat 
sebagai penanda ruh kebhinekaan ternyata belum terwujud. Belum semua elemen sekolah, baik guru, kepala sekolah dan pengelola lainnya memancarkan komitmen pribadi dalam mentransformasikan situasi "plural monokulturalisme" menuju situasi "plural-multikulturalisme" lewat berbagai medium aktivitas kesehariannya. Pembelajaran masih tampak datar, belum menjadikan pluralisme sebagai dinamika pembelajaran yang dapat membentuk segregasi sosial, seraya membuka ruang-ruang komunikasi bagi proses-proses interaktif, pertukaran gagasan, dan penyerbukan silang budaya.

Temuan lainnya, aktivitas yang muncul sebagai budaya kultural di sekolah lazimnya tak berbeda dengan sekolah lain. Misalnya, di pagi hari budaya salaman dan cium tangan kepada yang lebih tua, seperti guru, kepala sekolah, satuan pengamanan, dan lainnya selalu dilakukan. Cara untuk menghormati dan menghargai orang lain seperti itu juga lazim dilakukan di sekolah lain. Nilai keadilan yang berkaitan dengan hak-hak warga sekolah juga dalam bentuk keamanan sosial dan pengakuan timbal balik dalam perbedaan bentuk-bentuk budaya kehidupan, menurut sebagian besar responden, juga masih menjadi isu krusial yang belum memperoleh penguatan. Padahal, dalam menjaga Negara Kesatuan Republik Indonesia (NKRI), menurut semua responden, kata kuncinya adalah menjaga kebhinekaan meru-pakan keniscayaan, merupakan tugas semua pihak yang tak pernah berhenti, di mana pun berada. NKRI harus dijaga, salah satunya dengan membiasakan menjaga toleransi dan kohesi sosial di sekolah, tentunya diikuti yang berkeadilan. Keadilan memang bisa membantu persatuan, tetapi dengan keadilan saja tidak cukup. Persatuan punya gramatika sendiri, yaitu kohesi sosial (Latif, 2017).

Pengetahuan dan pemahaman tentang multikulturalisme harus terus diperjuangkan walaupun tidak mudah. Bagi bangsa yang beragam kultural tidak memerlukan keseragaman. Guru harus terus-menerus menerapkan kurikulum pendidikan yang sarat dengan nilainilai keragaman dengan cara mengelola dan merawat keberagaman, sehingga menghasilkan masyarakat yang penuh kerukunan, toleransi, dan penghargaan terhadap kemanusiaan. Meminjam istilah Yudhoyono, "Tak ada resep yang ajaib" (Yudhoyono, 2017). Selaras dengan hasil penelitian kualitatif terhadap guru di Republik Ceko yang dilakukan Moree, dkk. (2008) menunjukkan bahwa kurikulum dan pengajaran pendidikan multikultural telah menjadi kewajiban bagi sekolah dasar dan menengah. Temuan penelitian ini memberi makna bahwa sekolah hakikatnya dipandang sebagai suatu institusi sosial yang menjadi media proses penanaman nilai-nilai budaya dan kebersamaan hidup dalam keberagaman.

Kesadaran peran guru seperti itu membuat kehadiran implementasi kurikulum multikultural di sekolah dasar akan mampu mengkonstruksi pengetahuan siswa untuk melihat arah pengembangan perwujudan peradaban masa depan. Keadaban dapat dibentuk melalui nilai toleransi, moderasi, gotong royong, dan kerukunan di sekolah. Dengan begitu, keberagaman yang ada di sekolah juga akan tumbuh dengan baik dan menghasilkan identitas kewargaan ke-Indonesiaan yang bernas. Mayoritas responden sepakat, terbentuknya kewarganegaraan Indonesia karena pemahaman siswa atas perbedaan memperoleh bimbingan dari gurunya merupakan prasaratnya.

Hasil penelitian Blanchet-Cohen \& Di Mambro (2014) terhadap proyek-proyek lingkungan sebagai wahana keterlibatan anakanak SD imigran dalam komunitas mereka menunjukkan bahwa jika didukung oleh guru yang memiliki komitmen dan memfasilitasi mereka dengan cara menghargai dari aspek sosio-fisik dan estetika lingkungan, akan memberi rasa memiliki. Temuan ini mengindikasikan bahwa penerapan kurikulum multikultural yang digali dari pemahaman nilai keberagaman mampu menguatkan identitas kewargaan nasional siswa.

Dari dua alat pengumpul informasi yang diungkap di atas, tampak bahwa manajemen 
sekolah umumnya telah memahami posisi konstruksi ilmu pengetahuan pada kurikulum multikultural. Akan tetapi, secara paradoksal juga terjadi ketimpangan dalam implementasinya. Implementasi kurikulum multikutural yang habitus, yang mampu menorehkan toleransi dan tenggang rasa tampak masih belum kuat. Internalisasi nilai toleransi bermakna mampu memahami adanya perbedaan, belum membudaya di ruang-ruang kelas. Demikian pula nilai tenggang rasa, yaitu kemampuan mengendalikan diri dari sikap-sikap yang dapat menyinggung dan merendahkan identitas sesama warga sekolah yang berbeda agama, suku, ras, golongan, dan adat-istiadat dalam ranah pembelajaran juga tampak belum menjadi kebiasaan guru.

\section{Pengurangan Prasangka (Prejudice Reduction)}

Data yang dihimpun melalui diskusi kelompok terpumpun terungkap bahwa menurut semua responden pada hakikatnya pembelajaran sejatinya adalah membantu siswa agar memperoleh berbagai pengalaman, sehingga tingkah laku siswa bertambah baik, baik kuantitas maupun kualitas. Pengalaman tersebut meliputi pengetahuan, keterampilan dan nilai atau norma yang berfungsi sebagai pengendali sikap dan perilaku menjalani kehidupan wargabangsa Indonesia. Nilai-nilai kehidupan yang sebenarnya akan memunculkan kesadaran bagi siswa untuk mengekspresikan perasaan toleransinya bahwa Indonesia adalah negara multikultural, yang memerlukan warganya berbudaya Nusantara.

Temuan tersebut dapat dimaknai bahwa kebijakan kepala sekolah dalam mendesain implementasi kurikulum dikualifikasi sebagai kebijakan yang didaktis-konstruktif. Keberadaannya merupakan suatu pengurangan prasangka yang lahir dari interaksi keberagaman dalam kultur sekolah yang melatih kebajikan tampak telah dipahami. Kebajikan, menurut pandangan Brownlie \& Anderson (2016) dalam kajiannya tentang keterlibatan sosiologis dengan kebaikan, dapat mengubah bagaimana kita dapat merasakan tentang apa yang mereka lakukan. Hasil kajian ini memberikan bukti, bahwa sejumlah perilaku multikulturalisme mampu membawa kepingan bijak di tengah masyarakat dengan sikap hidup toleran, mengurangi prasangka, lebih reflektif dan kontemplatif untuk menjaga pluralisme.

Pertanyaannya, seberapa kuat peran semua guru saat mengajar di sekolah sampel dapat terlibat dalam penghapusan prasangka? Pertanyaan seperti itu sulit ditemukan jawabannya di sekolah. Walaupun prasangka dalam diri siswa, yang masih usia SD adalah sangat nyata. Dalam hal ini, Banks (2007) menyatakan siswa datang ke sekolah senantiasa disertai dengan prasangka terhadap kelompok-kelompok yang berbeda. Siswa yang datang ke sekolah dengan banyak prasangka, apabila merujuk hasil kajian Cavilla (2014) memperoleh diferensiasi kurikulum dan infus budaya melalui pendidikan secara baik akan memenuhi kebutuhan mereka. Telaah ini sejalan dengan hasil penelitian Walling (2016) yang menunjukkan bahwa $62 \%$ dari direktur yang mengajar di sekolah-sekolah internasional melaporkan penggunaan musik dari berbagai budaya saat praktik pengajaran multikultural telah mempengaruhi secara positif.

Indikator berkait dengan penggunaan metode mengajar guru untuk membantu siswa mengembangkan sikap rasial yang lebih positif, ditemukan dari observasi kelas belum memberikan perspektif multikulturalisme yang signifikan. Guru, yang umumnya satu agama dalam melaksanakan pembelajaran belum berafiliasi pada berbasis multikultural, seperti mengintegrasikan materi pembelajaran yang relevan dengan unsur-unsur terkait dengan multikulturalisme. Pembelajaran yang terjadi dapat dimaknai berlangsung seperti sediakala, penuh dengan pesan-pesan yang bersifat abstrak. Guru umumnya belum membantu siswa dalam mengembangkan perilaku positif tentang perbedaan kelompok, baik mengenai keagamaan, kesukuan maupun identitas lainnya. 
Misalnya, ketika siswa memiliki perilaku negatif dan terjadi kesalahpahaman terhadap keberadaan agama, suku, kelompok atau etnik lain, guru belum melakukan aksi yang dapat membantu mereka mengembangkan perilaku akomodatif dan yang lebih positif maupun menyediakan kondisi yang memiliki citra positif tentang perbedaan kelompok. Aktualisasi tentang nilai-nilai pluralisme tidak harus diingkari atau dipaksakan untuk seragam tetapi sebuah anugerah illahi yang sama-sama diwujudkan untuk kebaikan bersama. Sikap toleran agar dijadikan prasyarat mutlak yang harus dimiliki siswa dalam berinteraksi dan mestinya memperoleh penguatan.

Penguatan dimaksud merujuk hasil kajian Buckley \& Foldy (2010) yang telah mengembangkan sebuah model pedagogis terkait kompetensi konseling multikultural yang berfokus pada ras, rasisme, dan pengembangan identitas ras. Mereka merekomendasikan bahwa premis dasar proses mengajar serta pendekatan pembelajaran tambahan yang menekankan kehadiran pada jenis keselamatan, keamanan psikologis, dan keamanan identitas sebagai proses perkembangan seumur hidup dapat mengurangi prasangka negatif. Dari model ini tampak bahwa seorang guru pada saat di kelas dituntut memiliki kepekaan yang tinggi terkait dengan jaminan rasa aman diri siswa dari perlakuan stereotip negatif teman-temannya.

Munculnya prasangka dalam diri siswa kepada yang lain, menurut sebagian besar responden, memang tidak mudah dideteksi, tetapi diyakini ada. Persepsi responden tentang hal tersebut ditemukan dari hasil observasi, yang umumnya belum ada pemodelan dari guru yang menerapkan strategi pembelajaran yang lebih bersahabat dengan budaya lain. Misalnya, hasil kajian Lowenstein (2009) dapat dijadikan rujukan dalam mengajar yang menyatakan bahwa apabila guru melihat masa depan siswa memiliki sumber daya dan kemampuan untuk belajar maka guru harus kritis memeriksa dan dialog tentang apa yang mereka modelkan melalui pedagogi tersebut. Kajian ini memberi sinyal bahwa penggunaan buku teks pelajaran atau bahan pengajaran lain, strategi pembelajaran yang kooperatif dapat membantu siswa untuk mengembangkan perilaku dan persepsi terhadap toleransi yang lebih kuat.

Dalam konteks toleransi, Wilson (2014) dalam penelitiannya menemukan bahwa toleransi terjadi di mana-mana di seluruh Eropa. Bahkan, Dewan Eropa berupaya untuk membangun itu, sekolah diwajibkan untuk mengajarkannya. Hasil kajian Wilson (2014) ini memberi pesan bahwa pengalaman siswa dengan model penguatan terhadap latar belakang yang beragam akan mampu memberikan energi positif dalam penguatan kohesi sosial dan terajutnya ikatan kewargaan sekolah. Kondisi tersebut, linier dengan kenyataan bahwa masyarakat sekolah yang ada adalah majemuk, sehingga diperlukan nilai toleransi. Toleransi merupakan penghargaan kepada lainnya dan dibutuhkan keterbukaan sikap. Bahkan Bautista, dkk. (2017) dalam penelitiannya terhadap karakteristik pendidikan para guru pendidikan anak usia dini (PAUD) mendefinisikan keterbukaan pikiran sebagai kesediaan untuk mempertimbangkan pengalaman, keyakinan, nilai, dan perspektif yang berbeda dari keinginannya sendiri dalam mengayunkan toleransi.

Implementasi kurikulum multikultural menyangkut berbagai aspek kehidupan yang sangat penting dan tidak mengenal kata terlambat untuk dijadikan agenda bersama dalam hasanah aktivitas pembelajaran di sekolah, cukup dipahami oleh guru dan tenaga kependidikan. Namun, bentuk aksi-aksi dalam kerangka pengurangan prasangka negatif siswa yang bisa muncul, tampak belum secara signifikan dibumikan di sekolah. Misalnya, proses penerapan kurikulum multikultural yang dapat mengurangi gesekan prasangka negatif, seperti interaksi nilai-nilai sosial, memahami, peduli akan, dan bertindak atas dasar inti nilai keberagaman di antara beragam pemikiran dan nilai melalui mata pelajaran, sehingga menghasilkan habituasi yang pada akhirnya akan 
membentuk budaya sekolah, tampak belum mengenali dan berkembang dalam konteks kebersamaan. Implementasi kurikulum multikultural sebagai strategi pembentukan budaya pengurangan prasangka negatif di sekolah tampak belum mampu memberi kontribusi dalam proses penguatan bermakna toleransi sosial dan kebudayaan.

\section{Pedagogik Ekuitas/Kesetaraan (Equity Pedagogy)}

Implementasi kurikulum multikultural khas sekolah sampel yang menggambarkan satu pedagogik kesetaraan kans siswa (pedagogy equality of chance learners) di dalam ruangruang kelas, hasil dari observasi kelas, nampak belum menjadi kebiasaan. Kalimat-kalimat perintah guru yang biasa digunakan umumnya masih tunjuk nama, belum model demokrasi, misalnya, dengan cara undian nama-nama siswa. Demikian pula saat mengajar, guru umumnya masih berperan sebagai pemberi informasi, belum menjadi pendorong sikap mental siswa untuk bekerja, berkarya, dan berargumentasi dalam hal keragaman. Demikian benang merah hasil observasi sekolah dengan tenaga guru di sekolah.

Pada sisi lain, juga ditemukan bahwa guru umumnya masih melakukan penyeragaman pola berpikir dan bertindak yang difokuskan pada satu titik materi, tanpa melibatkan siswa secara adil dan setara untuk memberikan tanggapan, sumbangan pemikiran, atau sekadar bertanya. Pembelajaran yang terjadi cenderung satu arah, dengan penekanan pada aspek normatif-kognitif daripada tentang apa yang siswa butuhkan untuk bersosialisasi dengan berbagai keragaman. Temuan ini sepertinya juga menjadi parameter bahwa pembelajaran yang mengusung prinsip keberagaman masih jauh dari harapan. Demikian pula, aktivitas produksi sosial berbasis kesetaraan teman sebaya melalui berbagai dinamika pembelajaran di kelas umumnya juga belum menjadi habituasi. Manakala hal seperti itu timbul, Galeotti (2010) mengusulkan pertimbangan ulang secara umum tentang perjuangan budaya dan identitas yang merupakan bahan multikulturalisme. Artinya, sekolah didorong mendesain ulang dalam kerangka penguatan nilai-nilai multikulturalisme.

Pembelajaran cenderung belum meletakkan dasar dengan suguhan-suguhan tentang senyatanya kehidupan, misalnya dalam satu kelas ada siswa yang beda agama. Bagaimana menyikapi hal ini? Apa yang harus guru lakukan? Model konkret seperti apa dalam menghargai yang berbeda itu. Misalnya, perlukah di kelas dilakukan saling doa dengan siswa yang berbeda agama. Sejumlah temuan itu, menandakan bahwa siswa belum diajak membiasakan sebuah ritual nilai tentang kehidupan yang berbeda dari dirinya. Artinya, pendekatan pedagogis guna pemberian ruang dan kesempatan yang sama bagi yang lain masih kurang tampak. Temuan ini mengindikasikan bahwa aktivitas dalam kelas yang mestinya penuh dengan nilai-nilai multikulturalisme tampak belum dibiasakan dengan semangat damai dan cinta kepada sesama.

Esensi pembelajaran di samping mempelajari hal-hal yang bersifat akademis, pembekalan kepribadian tentang kesetaraan penting artinya untuk menghadapi lingkungan dalam situasi apa pun. Guru di kelas mesti menciptakan citra yang cukup kuat untuk menularkan contoh konkrit yang diwujudkan melalui pedagogik kesetaraan yang relevan dengan realitas. Dengan begitu, guru memiliki andil besar dalam memekarkan eksistensi kemanusiaan dan bukan sekadar agar manusia dapat hidup secara biologis semata. Penegasan bahwa eksistensi sekolah tidak nominal terus-menerus, tetapi menjadi satu realitas yang tak terbantah. Kerangka pikir seperti itu, sejalan dengan hasil penelitian David (2011) yang menemukan bahwa pertimbangan konseptual tentang ekuitas/kesetaraan dan keragaman sebagai kunci untuk mengembangkan kebijakan, praktik, dan pedagogi untuk masa depan dalam menghadapi abad ke-21.

Artinya, dalam mengawal pembelajaran, komitmen seorang guru senantiasa dituntut mampu memberi contoh bagaimana memperlakukan siswa tanpa membedakan asal-usulnya. 
Praksis pembelajaran seperti itu, selaras dengan Naraian (2016) ketika mengungkapkan hasil penelitiannya terhadap siswa dalam pendidikan khusus bahwa komitmen guru hendaknya lebih memberikan pendekatan eklektik dalam bentuk pedagogi inklusif kepada siswa disabilitas. Hasil penelitian ini memberi penegasan apabila guru mengajar hendaknya memiliki strategi pedagogi yang mengetengahkan kesetaraan kepada semua anak didiknya yang memiliki keragaman. Jadi, semangat dasarnya adalah harus pengajaran yang setara dan berkeadilan.

Meskipun kemajemukan yang ada di sekolah sampel relatif tidak mencolok (lihat Tabel 1 ), namun, kegiatan menerapkan kurikulum multikulturalisme seharusnya menjadi keniscayaan, apalagi kenyataan hidup yang akan dihadapi siswa, memang penuh kemajemukan. Merayakan Hari Raya Idul Fitri, misalnya, seperti halnya hari besar agama lain, mestinya menjadi simbol kebersamaan dan keberagaman bagi komunitas sekolah. Bentuk internalisasi nilai seperti itu, belum dibiasakan di sekolah. Aktivitas hari raya keagamaan yang gempita umumnya baru dilakukan sebatas pada satu agama tertentu semata. Program kepala sekolah tampak belum prokeberagaman. Padahal, kecenderungan pola kepemimpinan yang propembudayaan, penghayatan, dan pengamalan nilai-nilai kewargaan yang multikultural merupakan keniscayaan. Dalam konteks ini, Santamaría (2013) dalam penelitiannya merekomendasikan perlunya alternatif model kepemimpinan sebagai respon terhadap keanekaragaman di sekolah dan nilai dalam mengeksplorasi hubungan antara pendidikan multikultural dan kepemimpinan pendidikan, perlu menjadi perenungan.

Setiap siswa di setiap sekolah belum secara alamiah mampu mengemban tugas dan tanggung jawab menyelesaikan pekerjaan yang bersentuhan dengan multikulturalisme. Siswa umumnya belum terlatih dan tertantang menyelesaikan tugas-tugas dengan masalah keberagaman, misalnya, apa yang siswa pikirkan kalau temanmu yang sakit berbeda agama?
Tugas semacam ini, tampak sederhana, tetapi dapat dikembangkan menuju budaya multikulturalisme, yang berguna bagi lulusan dalam kehidupan bermasyarakat. Contoh lain yang ditemukan misalnya, berdoa dalam kelas umumnya masih diwarnai oleh satu agama. Padahal, terdapat siswa yang berbeda agama.

Adanya siswa yang berbeda agama seharusnya juga menjadi perenungan seorang guru, aksi apa yang bersesuaian dengan kondisi seperti itu. Guru, selayaknya memiliki jiwa "pengorbanan" sebagaimana diungkapkan oleh Dollahite, dkk. (2009) tentang pengorbanan tujuh puluh tujuh remaja di 55 keluarga religius Yahudi, Kristen, Muslim, dan Mormon di New England dan California menunjukkan bahwa mereka memandang pengorbanan dilakukan karena alasan agama dengan pertimbangan pada lima domain: harapan masyarakat, budaya populer, kenyamanan dan kesenangan, waktu dan aktivitas, dan hubungan sesama. Penelitian ini memberi makna bahwa penguatan nilai-nilai multikulturalisme membutuhkan perjuangan dan pengorbanan berbagai pihak.

Model pengajaran guru yang mengetengahkan pedagogis kesetaraan terhadap keragaman siswanya masih belum adekuat. Padahal, menurut penelitian Brown (2004) tentang keragaman budaya tingkat SMP menegaskan, guru seyogianya menerima pesan bahwa "guru kelas harus multikultural" dan "guru dibebankan dengan ajaran multikultural." Pesan tersebut dapat memicu beberapa perubahan dalam kepekaan keragaman budaya, namun metodologi yang digunakan untuk mengurangi resistensi dan pengasuhan serta penguatan pesan memiliki pengaruh yang lebih besar. Jelas bahwa hasil penelitian ini memberi panduan manakala seorang guru mampu meningkatkan peran dalam mengelola keberagaman pengaruhnya dapat menguatkan kohesi sosial.

Dalam konteks pemahaman konsep, data yang dihimpun melalui diskusi kelompok terpumpun terungkap bahwa semua responden paham dan sepakat agar seorang guru selalu memikirkan yang terbaik bagi anak didiknya. 
Bagaimana membimbing, menghadapi mereka, mengarahkan mencapai tujuan, berbuat adil untuk semua, dan mengelola siswa dalam menempuh proses pendidikan yang memberi ruang dan kesempatan yang setara dan sama. Semua responden menyadari, banyak tujuan yang diinginkan oleh siswa setelah mengikuti proses pembelajaran, satu di antaranya ialah tentang nilai menghargai kemajemukan. Responden memahami bahwa nilai tidak pernah ada akhirnya, berbeda dengan tujuan apabila telah tercapai maka berakhirlah aktivitasnya. Tujuan bersekolah adalah menyelesaikan jenjang SD, begitu tamat SD maka selesailah tujuan itu. Menghargai, misalnya, tidak akan pernah berakhir, nilai itu akan tetap relevan sampai kapan pun.

Dalam kurikulum multikultural, nilai adalah keseluruhan ciri aneka varietas mata pelajaran yang mesti dibangun di sekolah. Bahkan, Joesoef mengatakan kalau pendidikan bertujuan mengetahui bukan fakta, melainkan nilai (Latif, 2017). Oleh karena itu, saat bersekolah siswa harus mendapat pemahaman, perasaan, dan internalisasi tentang nilai-nilai. Dia perlu memperoleh makna yang jernih mengenai keindahan dan kebaikan moral kepada sesama. Padahal, tugas guru dalam konteks pengimplementasian kurikulum multikultural adalah menjabarkan kompetensi yang terdapat dalam mata pelajaran yang mengandung nilai-nilai untuk diajarkannya dengan pola pedagogis kesetaraan (equity pedagogy).

\section{Pemberdayaan Budaya Sekolah (Empowering School Culture)}

Salah satu jalan pembentukan budaya sekolah, menurut hampir semua (83\%) responden ialah pemberdayaan. Mereka menyatakan, budaya sekolah tidak mungkin akan terwujud manakala manajemen sekolah tidak menerapkan model pemberdayaan sebagai pemacu dalam menggerakkan seluruh potensi yang ada. Tidak hanya itu, penciptaan suasana atau iklim kerja sekolah yang memungkinkan potensi setiap orang berkembang, juga diungkapkan sebagai hal yang penting. Beberapa hal tersebut terungkap melalui diskusi kelompok terpumpun yang dilakukan dua mingguan sekali. Pernyataan sebagian besar responden, ternyata sejalan dengan studi kasus yang dilakukan oleh Kirk dkk. (2016) terhadap beragam etnis SMA perkotaan di Midwest Amerika Serikat yang memberikan pandangan bahwa model pemberdayaan adalah kerangka yang berguna untuk perbaikan sekolah, menambah "kekuatan" yang lebih luas terhadap iklim sekolah, dan memperluas kinerja sekolah. Hasil penelitian ini memberi penegasan bahwa budaya sekolah yang positif akan terbentuk manakala disertai dengan kinerja sekolah yang juga baik dengan mengedepankan pola pemberdayaan.

Baik dan tidaknya kinerja sekolah, salah satu parameternya adalah seberapa kuat manajemen sekolah mampu mewujudkan bidangbidang garapan problematikanya, satu di antaranya adalah terkait budaya multikulturalisme yang menjadi program unggulan. Namun, pandangan itu tampaknya belum membentuk budaya bersama dan hasrat untuk satu. Dalam sesi diskusi berikutnya, terungkap pula bahwa semua belum bertanggung jawab dan belum menjadi bagian dalam merawat kebhinekaan,jadi, masih kepala sekolah sentris.

Hasil yang didapat dari diskusi kelompok terpumpun juga terungkap bahwa pemberdayaan guru yang relatif baru berjalan. Pemberdayaan yang terjadi pun, masih normatif, seperti pembagian tugas mengajar, pembagian tugas jam piket menjaga siswa, kepanitiaan penerimaan siswa baru, dan kegiatan lain di sekolah yang umumnya berhubungan dengan akademis. Agenda kegiatan bersifat penguatan budaya multikulturalisme belum diprogramkan. Demikian pula pemberdayaan trisentra pendidikan, khususnya keterlibatan orangtua siswa, masyarakat sekitar, dan sumber daya lain masih ditemukan kendala. Temuan ini mengindikasikan bahwa domain pemberdayaan dalam kerangka melaksanakan aktivitas kebijakan program guna membangun budaya multikultural di sekolah belum kuat. Semua alasan yang diungkap di 
atas lebih menge-mukakan rasionalitas, tetapi lemah dihadapkan dengan aksi-aksinya.

Pemberdayaan warga sekolah dalam menyugesti siswa untuk berbuat kebajikan sebagai proses habituasi merupakan kebijakan yang bermakna proaktif dalam kerangka pikir implementasi kurikulum multikultural. Contoh, selama ini kebijakan tentang multikulturalisme yang diterapkan di pondok pesantren telah berhasil cukup signifikan karena didukung oleh adanya kurikulum pendidikan pesantren yang sarat dengan muatan paham-paham multikulturalisme. Premis tersebut diangkat berdasarkan studi Hasyim (2006) yang menemukan bahwa sikap toleransi, penghargaan terhadap perbedaan, dan semangat multikulturalisme cukup jelas ditanamkan melalui kitab kuning (turas Islam).

Berangkat dari suatu keanekaragaman kultural adalah sebuah fakta sosial (demografis maupun geografis) di dalam kenyataan aktual bahwa negara-bangsa Indonesia terdiri atas berbagai kelompok etnis, kelas sosial, budaya, agama, dan lain-lain, sehingga negara-bangsa Indonesia secara sederhana dapat disebut sebagai kumpulan masyarakat superetnik. Dari semua latar itulah negara-bangsa Indonesia menemukan kenyataan sosial dan budaya yang multikultural, sebagai konsekuensi alamiah yang tak terelakkan yang perlu penguatan dalam kurikulum. Pentingnya pemberdayaan dalam penerapan nilai-nilai multikultural mestinya bukan hanya didominasi para pelaksana kebijakan pendidikan. Contohnya, penelitian De Bruin (2010) tentang seri polisi Belanda Baantjer dan Spangen yang ditayangkan melalui drama televisi populer menawarkan kepada pemirsa kesempatan untuk membahas tema yang menonjol dalam masyarakat multikultural Belanda dapat dijadikan inspirasi. Hasil penelitian ini memberi makna bahwa isu multikultural telah membawa upaya dalam mempersatukan kajian-kajian keberagaman pada setiap momen pendidikan.

Sementara itu, observasi yang dilakukan terhadap konteks pemberdayaan guna memotret budaya sekolah, dapat dimaknakan cukup punya bekal untuk merekam jejak sosial dan kultural di sekolah sampel. Sejak pertama kali melakukan observasi, awal Agustus 2016, dan bertemu dengan komunitas sekolah, ada kesan sekolah seolah belum menyuarakan keharmonisan antara budaya pendidikan, kultur, dan multikulturalisme kepada komunitasnya melalui model pemberdayaan. Data semacam itu, dapat dijumpai di dalam upaya pemberdayaan siswa yang belum dipandang di samping untuk memperkuat daya juga untuk mencegah terjadinya pengelompokan yang tidak seimbang, serta menciptakan kebersamaan dan kemitraan antarmereka dalam meningkatkan pengetahuan yang berdampak pada kesadaran multikultural.

Pemberdayaan tampak ada, tetapi sifatnya lebih pada sasaran bidang akademis, belum pada pengawalan untuk menemukenali kekhasan potensi sekolah yang bisa ditarik ke dalam ranah pembelajaran yang sarat dengan nilai multikulturalisme sekaligus mampu menempatkan guru dalam konteks kebersamaan. Premis semacam itu, dapat merujuk pada hasil penelitian Elkader (2016) yang menyarankan pendekatan pendidikan yang lebih demokratis menuju mengajar topik kontroversial kurikulum multikultural yang disebut multikulturalisme kritis melalui dialogis pedagogi. Karenanya, dapat dimaknai sekolah belum kuat mengetengahkan internalisasi nilainilai multikulturalisme melalui pemberdayaan, tetapi masih sekadar fakta, seperti upacara bendera, beribadah bersama, merayakan harihari besar keagamaan dan nasional.

Konteks pemberdayaan kepada komunitas sekolah tentang budaya multikulturalisme merupakan suatu proses yang membiasakan siswa menggali, mempelajari, menguasai nilai, dan menerapkannya demi kecerahan pribadi, keluarga, dan masyarakat karena sama-sama mengakui kebajikannya mestinya dijadikan kebiasaan, bahkan budaya sekolah dan struktur sosial. Misalnya, menciptakan kondisi saling menghargai dan saling ketergantungan siswa yang didasari nilai-nilai multikultural. 


\section{SIMPULAN DAN SARAN}

\section{Simpulan}

Dari hasil penelitian dan pembahasan di atas dapat disimpulkan bahwa implementasi kurikulum multikultural di sekolah saat ini umumnya belum berubah ke arah yang lebih baik. Secara khusus, ditemukan lima rincian simpulan. Pertama, dokumen perangkat kurikulum yang digunakan di sekolah umumnya telah mengintegrasikan nilai-nilai multikulturalisme dan juga tidak mengandung unsur kata, ilustrasi, gambar, ajakan atau ungkapan prasangka negatif yang mendiskreditkan keberagaman. Kedua, guru dan tenaga kependidikan di sekolah umumnya secara cukup signifikan memahami pengetahuan tentang multikultural baik yang tersurat maupun yang tersirat dalam kurikulum. Ketiga, wujud pengimplementasian kurikulum dalam kerangka pengurangan prasangka negatif terhadap keberagaman yang dilakukan baik oleh siswa, guru maupun tenaga kependidikan yang muncul umumnya belum secara signifikan dapat dikendalikan dengan baik di sekolah. Keempat, secara pedagogis penugasan-penugasan yang diberikan kepada siswa dalam kegiatan pembelajaran di kelas umumnya belum secara signifikan mendorong upaya penguatan nilai-nilai menghargai kemajemukan di bidang-bidang perbaikan kehidupan. Kelima, dalam implementasi kurikulum multikultural umumnya belum secara signifikan menyuarakan keharmonisan antara budaya pendidikan, kultur, dan multikulturalisme kepada komunitas sekolah untuk saling berinteraksi melalui model pemberdayaan.

\section{Saran}

Berdasarkan simpulan penelitian yang diungkapkan di atas, saran-saran yang perlu disampaikan antara lain. Pertama, ditinjau dari perspektif implementasi kurikulum multikultural, pembelajaran hendaknya diarahkan dan dikuatkan untuk mewujudkan praktik baik guna mengerti bagaimana menghargai dan bertanggung jawab mengenai keberagaman budaya, suku, agama, dan keyakinan. Kedua, keberagaman yang ada di sekolah hendaknya dirawat dengan baik untuk menghasilkan ke-Indonesiaan yang bermakna dan sekaligus membentuk citra sekolah yang ramah dengan keragaman. Ketiga, komunitas sekolah hendaknya berkomitmen mengetengahkan budaya bernalar dan akal sehat dalam membawa kemajemukan ke masyarakat dengan disertai sikap hidup toleran, lebih reflektif, dan kontemplatif untuk menjaga kemajemukan. Keempat, pentingnya arti implementasi kurikulum pendidikan multikultural, hendaknya dimaknai sebagai berangkat dari pengetahuan, pemahaman, penghayatan, dan aktualisasi nilai-nilai oleh komunitas sekolah secara utuh dan berkelajutan dalam menerima senyatanya kemajemukan. Kelima, guru dan tenaga kependidikan dalam mengimplementasikan kurikulum multikultural di sekolah dasar hendaknya selalu mendorong tatanan masyarakat sekolah dengan mengutamakan persamaan (equality) atau mengedepankan keberagaman (diversity) sebagai manifestasi dari rasa tanggung jawab dan kepedulian terhadap bangsanya yang bersifat pluralistik.

\section{PUSTAKA ACUAN}

Agirdag, O., Merry, M. S. \& Van Houtte, M. 2016. Teachers' Understanding of Multicultural Education and the Correlates of Multicultural Content Integration in Flanders, Education and Urban Society, 48(6), 556-582.

Arneil, B. \& F. MacDonald. 2010. Multiculturalism and the Social Sphere, dalam The Ashgate Research Companion to Multiculturalism, D. Ivison (ed.), 95-117. London: Routledge.

Bachvarova, M. 2014. Multicultural Accommodation and the Ideal of Non-Domination. Critical Review of International Social and Political Philosophy, 17(6), 652-673.

Banks, J. A. \& Banks, C. A. M (Eds.). 2004. Handbook of Research on Multicultural Education. 2nd Ed. San Francisco: Jossey-Bass. 
Banks, J. A. 2007. Educating Citizens in A Multicultural Society (2nd ed.). New York: Teachers College Press.

Banting, K., Johnston, R., Kymlmicka, W., \& Soroka, S. 2006. "Do Multiculturalism Policies Erode the Welfare State? An Empirical Analysis," in Multiculturalism and the Welfare State, $\mathrm{K}$. Banting and W. Kymlicka (eds.), 49-91. Oxford: Oxford University Press.

Bautista, N., Misco, T. \& Quaye, S. J. 2017. Early Childhood Open-Mindedness: An Investigation Into Preservice Teachers' Capacity to Address Controversial Issues. Journal of Teacher Education, 1-15. DOI: https://doi.org/10.1177/0022487117702575.

Betts, K. R. \& Hinsz, V. B. 2013. Group Marginalization: Extending Research on Interpersonal Rejection to Small Groups. Personality and Social Psychology Review, 17(4), 355-370.

Blanchet-Cohen, N. \& Di Mambro, G. 2014. Environmental Education Action Research with Immigrant Children in Schools: Space, audience and influence. Action Research, 13(2), 123-140.

Brownlie, J \& Anderson, S. 2016. 'Thinking Sociologically About Kindness: Puncturing The Blasé in The Ordinary City' Sociology, 1-17. DOI: $10.1177 / 0038038516661266$

Brown, E. L. 2004. What Precipitates Change in Cultural Diversity Awareness during a Multicultural Course: The Message or the Method? Journal of Teacher Education, 55(4), 325-340.

Buckley, T. R. \& Foldy, E. G. 2010. A Pedagogical Model for Increasing Race-Related Multicultural Counseling Competency $1 \Psi$ 7. The Counseling Psychologist, 38(5), 691-713.

Cavilla, D. 2014. Thoughts on Access, Differentiation, and Implementation of A Multicultural Curriculum. Gifted Education International, 30(3), 281-287.

David, Miriam E. 2011. Learning from Innovative International Research on Higher Education: How to Conceptualise Equity for Policy, Practice and Pedagogies in Higher Education. Research in Comparative and International Education, 6(4), 430-443.

De Bruin, J. 2010. Young People and Police Series: A Multicultural Television Audience Study. Crime, Media, Culture, 6(3), 309-328.

Dollahite, D. C., Layton, E., Bahr, H. M., Walker, A. B. \& Thatcher, J. Y. 2009. Giving Up Something Good for Something Better: Sacred Sacrifices Made by Religious Youth. Journal of Adolescent Research, 24(6), 691-725.

Dominguez, S. \& Hollstein, B. (Eds.). 2014. Mixed Methods Social Networks Research Design and Applications. New York: Cambridge University Press.

du Plessis, E. \& Marais, P. 2015. A Grounded Theory Perspective on Leadership in Multicultural Schools. Journal of Asian and African Studies, 52(5), 722-737 doi: 10.1177/ 0021909615612122

Elkader, N Abd. 2016. Dialogic Pedagogy and Educating Preservice Teachers for Critical Multiculturalism. SAGE Open, 6, 1-13.

Engelkamp, S. \& Glaab, K. 2015. Writing Norms: Constructivist Norm Research and the Politics of Ambiguity. Alternatives, 40(3-4), 201-218.

Faas, D. \& Ross, W. 2012. Identity, Diversity and Citizenship: A Critical Analysis of Textbooks and Curricula in Irish schools. International Sociology, 27(4), 574-591.

Ford, Derek R. 2014. Review of Tyson E. Lewis. On study: Giorgio Agamben and educational potentiality. Studies in Philosophy and Education, 33(1), 105-111. 
Ford, D. Y. 2013. Why Education Must Be Multicultural, Addressing a Few Misperceptions With Counterarguments. Gifted Child Today, 37(1), 59-62.

Galeotti, A. E. 2010. Multicultural Claims and Equal Respect. Philosophy \& Social Criticism, 36(34), 441-450.

Gordijn, E., Finchilescu, G., Brix, L., Wijnants, N. \& Koomen, W. 2008. The Influence of Prejudice and Stereotypes on Anticipated Affect: Feelings about a Potentially Negative Interaction with Another Ethnic Group. South African Journal of Psychology, 38(4), 589-601.

Grice, J. W., Yepez, M., Wilson, N. L. \& Shoda, Y. 2016. Observation-Oriented Modeling: Going Beyond "Is It All a Matter of Chance"? Educational and Psychological Measurement.

Hasyim, S. 2006. Belajar Multikulturalalisme dari Pesantren. Jurnal Al-Wasathiyyah, 1(1).

Heryadi, H. \& Silvana, H. 2013. Komunikasi Antarbudaya dalam Masyarakat Multikultural. Jurnal Kajian Komunikasi, 1(1), 95-108.

Joesoef, D. 2017. Memikir Ulang Pendidikan, Kompas, 25/1/2017, Hal. 6.

Keddie, A. 2014. Australian Multicultural Policy: Social Cohesion Through a Political Conception of Autonomy. Journal of Sociology, 50(4), 408-421.

Kirk, C. M., Lewis, R. K., Brown, K., Karibo, B., Scott, A. \& Park, E. 2016. The Empowering Schools Project: Identifying the Classroom and School Characteristics That Lead to Student Empowerment. Youth \& Society, $0(0)$.

Latif, Y. 2017. Kemajemukan Butuh Keadilan: Penolakan Multikulturalisme Dipicu Ketidakadilan, Harian Kompas. 10 Februari 2017, Hal. 12

Leung, Ka-yee A. \& Chiu, Chi-yue. 2010. Multicultural Experience, Idea Receptiveness, and Creativity. Journal of Cross-Cultural Psychology, 41(5-6), 723-741.

Lie, J. (ed.). 2014. Multiethnic Korea? Multiculturalism, Migration, and Peoplehood Diversity in Contemporary South Korea. Berkeley: Institute of East Asian Studies, University of California, Berkeley.

Lowenstein, K. L. 2009. The Work of Multicultural Teacher Education: Reconceptualizing White Teacher Candidates as Learners. Review of Educational Research, March 2009; 79(1) 163-196.

Lykogianni, R. 2008. Tracing Multicultural Cities From the Perspective of Women's Everyday Lives. European Urban and Regional Studies, 15(2) 133-143.

Maddux, W. W., Bivolaru, E., Hafenbrack, A. C., Tadmor, C. T. \& Galinsky, A. D. 2014. Expanding Opportunities by Opening Your Mind: Multicultural Engagement Predicts Job Market Success Through Longitudinal Increases in Integrative Complexity. Social Psychological and Personality Science, 5(5) 608-615.

Maddux, W. W., Adam, H. \& Galinsky, A. D. 2010. When in Rome ... Learn Why the Romans Do What They Do: How Multicultural Learning Experiences Facilitate Creativity. Personality and Social Psychology Bulletin, 36(6) 731-741.

Mentz, K. \& van der Walt, J. L. 2007. Multicultural Concerns of Educators in the Western Cape Province of South Africa. Education and Urban Society, 39(3) 423-449.

Miafodzyeva, S., Brandt, N. \& Andersson, M. 2013. Recycling behaviour of householders living in multicultural urban area: a case study of Järva, Stockholm, Sweden. Waste Management \& Research, 31(5), 447-457. 
Mitchell, A. 2010. Peace Beyond Process? Millennium - Journal of International Studies, 38(3) 641-664.

Moree, D., Klaassen, C. \& Veugelers, W. 2008. Teachers' Ideas about Multicultural Education in a Changing Society: The Case of the Czech Republic. European Educational Research Journal, 7(1) 60-73.

Naraian, S. 2016. Teaching for "Real": Reconciling Explicit Literacy Instruction With Inclusive Pedagogy in a Fourth-Grade Urban Classroom. Urban Education, 0(0).

Nurhayati, A. 2011. Menggagas Pendidikan Multikultur di Indonesia. Jurnal Al-Tahrir, 11(2), 327347.

Okoye-Johnson, O. 2011. Does Multicultural Education Improve Students' Racial Attitudes? Implications for Closing the Achievement Gap. Journal of Black Studies. 42(8), 12521274.

Olmedo, I. M., 2004. Raising Transnational Issues in a Multicultural Curriculum Project. Urban Education, 39(3), 241-265.

Peterson, M. F. \& Søndergaard, M. 2011. Traditions and Transitions in Quantitative Societal Culture Research in Organization Studies. Organization Studies, 32(11), 1539-1558.

Purwanto, J., Suwandi, S., \& Wardhani, N. E. 2013. Pendidikan Multikultural dalam Buku Pelajaran Bahasa Indonesia Non-BSE untuk Siswa SMP di Surakarta. Jurnal Pendidikan Bahasa dan Sastra, 1(1), 12-26.

Rutland, A., Killen, M., \& Abrams, D. 2010. A New Social-Cognitive Developmental Perspective on Prejudice: The Interplay Between Morality and Group Identity. Perspectives on Psychological Science, 5(3), 279-291.

Santamaría, L. J. 2013. Critical Change for The Greater Good: Multicultural Perceptions in Educational Leadership Toward Social Justice and Equity. Educational Administration Quarterly, 50(3), 347-391.

Schoorman, D. \& Bogotch, I. 2010. What is a Critical Multicultural Researcher? A Self-Reflective Study of The Role of The Researcher. Education, Citizenship and Social Justice, 5(3), 249-264.

Solano-Campos, A. 2015. Children's National Identity in Multicultural Classrooms in Costa Rica and The United States. Research in Comparative and International Education, 10(1), 7194.

Thompson, J., Bakken, L. \& Wei-Cheng, M. 2009. Equity Education: A Longitudinal Study Comparing Multicultural Knowledge and Dispositions of Field-Based and Campus-Based Teacher Candidates. Policy Futures in Education, 7(4), 416-422.

Tilaar, H.A.R. 2004. Multikulturalisme Tantangan-tantangan Global Masa Depan dalam Transformasi Pendidikan Nasional. Jakarta: PT Grasindo.

Trauna, D. S. 2010. Pendidikan Agama Islam Berwawasan Multikulturalisme. Jakarta: Kementerian Agama.

Walling, C. B. 2016. Secondary Choral Directors' Multicultural Teaching Practices, Attitudes and Experiences in International Schools. International Journal of Music Education, 34(2), 196-207.

Wihardit, K. 2010. Pendidikan Multikultural: Suatu Konsep, Pendekatan dan Solusi. Jurnal Pendidikan, 11(2). 
Wilson, H. F. 2014. The Possibilities of Tolerance: Intercultural Dialogue in a Multicultural Europe. Environment and Planning D: Society and Space, 32(5) 852-868.

Yudhoyono, S. B. 2017. Menjawab Tantangan 2017, Harian Kompas, 9 Januari 2017, Hal. 6.

Zuriah, N. 2011. Model Pengembangan Kewarganegaraan Multikultural Berbasis Kearifan Lokal dalam Fenomena Sosial Pasca Reformasi di Perpendidikan Tinggi. Jurnal Penelitian Pendidikan, 11(2), 75-86. 
Sutjipto, Implementasi Kurikulum Multikultural di Sekolah Dasar

Jurnal Pendidikan dan Kebudayaan, Vol. 2, Nomor 1, Juni 2017 